\title{
PENGARUH PENAMBAHAN TEPUNG AMPAS TAHU TERHADAP KARAKTERISTIK BISKUIT YANG DIHASILKAN
}

\author{
Sartika Yuliani ${ }^{(1)}$, dan Hermiza Mardesci, S.TP., MP ${ }^{(2)}$ \\ (1) Alumni Teknologi Pangan Faperta UNISI \\ (2) Dosen Teknologi Pangan Faperta UNISI \\ mimzaaci@yahoo.co.id
}

\begin{abstract}
Abstrak
Biskuit merupakan produk kering yang pada saat pengolahan melalui proses pemanggangan, selain itu biskuit merupakan produk yang di gemari oleh seluruh kalangan usia dikarenakan memiliki tekstur yang gurih biskuit juga mudah dibawa karena memiliki volume yang ringan. Dikarenakan biskuit merupakan makanan yang digemari terutama untuk anak-anak maka perlu penambahan bahan-bahan yang tinggi akan kandungan nutrisi dan salahsatunya tepung ampas tahu dan kacang hijau. Penambahan tepung ampas tahu dikarenakan ampas tahu merupakan limbah padat yang diperoleh dari proses pembuatan tahu dari kedelai, Selain menggunakan tepung ampas, bahan lain yang digunakan yaitu tepung kacang hijau hal ini dikarenkan kacang hijau memiliki kandungan nutrisi yang tinggi. Tujuan penelitian ini adalah Mengetahui pengaruh penambahan tepung ampas tahu terhadap kadar protein, kadar abu dan kadar air, warna, tekstur, rasa dan aroma biskuit dan mengetahui perbandingan yang tepat antara tepung ampas tahu dan kacang hijau, yaitu 0\%, 10\%, $20 \%$ dan $30 \%$ terhadap karakteristik biskuit. Berdasarkan hasil penelitian tepung ampas tahu yang ditambahkan bahwa perlakuan terbaik adalah perlakuan B (30\% tepung ampas tahu) dengan dengan kadar air sebesar 7,14\%, kadar abu sebesar $0,94 \%$, kadar protein sebesar $10,00 \%$, dan skor organoleptik warna sebesar 3,80, tekstur 4,05, rasa 4,00 dan aroma 3,60.
\end{abstract}

Kata Kunci: Biskuit, Ampas Tahu, Kacang Hijau

\section{PENDAHULUAN}

Di Indonesia tahu merupakan makanan padat yang dicetak dari susu kedelai dengan proses pengendapan protein pada titik isoelektrik tanpa atau dengan penambahan bahan lain yang diijinkan (Sarjono, 2006). Tahu yang kaya akan protein sudah sejak lama di konsumsi oleh masyarakat Indonesia sebagai lauk.

Tahu adalah makanan yang dibuat dari kacang kedelai yang difermentasi dan diambil sarinya, Tahu adalah kata serapan dari bahasa Hokkian (tauhu) hanyu pinyin : doufu) yang secara harfiah berarti kedelai yang difermentasi. Tahu pertama kali muncul di Tiongkok sejak zaman Dinasti Han sekitar 2200 tahun yang lalu yang ditemukan oleh seorang bangsawan, cucu dari kaisar Han Gaozu, Liu Bang yang mendirikan Dinasti Han (Elfidia, 2014).

Berdasarkan data Badan Pusat Statistik (BPS) tahun 2015 produksi kacang kedelai di Provinsi Riau tercatat 2145 ton, bila 50\% kacang kedelai tersebut digunakan untuk membuat tahu dan konversi kacang kedelai menjadi ampas tahu sebesar 100-112\% maka 
jumlah ampas tahu tercatat 1201, 2 ton (Sirossiris, 2011).

Tahu merupakan pangan yang tinggi akan protein yaitu 7,9\% sehingga bermanfaat bagi pertumbuhan dan kesehatan tubuh manusia, namun pada saat proses pengolahannya tahu menghasilkan limbah yang disebut ampas tahu.

Ampas tahu merupakan limbah padat yang diperoleh dari proses pembuatan tahu dari kedelai, Ampas tahu dapat disebut juga sisa barang yang telah diambil sarinya atau patinya atau limbah industri pangan yang telah diambil sarinya melalui proses pengolahan, Masyrakat pada umumnya memanfaatkan ampas tahu untuk pakan ternak dan sebagian dipakai sebagai bahan dasar pembuatan tempe gambus (Saputro, 2015).

Ampas tahu memiliki komposisi nutrisi yang tinggi yaitu $17,4 \%$ protein, 4,3\% mineral, $19 \%$ kalsium, $29 \%$ fosfor, $398 \%$ energy, 67, 5\% kharbohidrat $4 \%$ zat besi sehingga ampas tahu bermanfaat untuk pertumbuhan dan kesehatan tubuh (Surparti dalam Gustina, 2012). Ampas tahu selain digunakan sebagai pakan ternak juga dapat diolah menjadi produk pangan yaitu tepung, stick, kerupuk dan produk yang betekstur keras lainnya yaitu biskuit.

Biskuit adalah produk kering yang pada saat pengolahan melalui proses pemanggangan, selain itu biskuit merupakan produk yang di gemari oleh seluruh kalangan usia dikarenakan memiliki tekstur yang gurih biskuit juga mudah dibawa karena memiliki volume yang ringan. Dikarenakan biskuit merupakan makanan yang digemari terutama untuk anak-anak oleh karena itu pencampuran tepung ampas tahu yang tinggi akan nutrisi terutama protein kedalam proses pembutan biskuit bisa menjadi salah satu alternatif pangan yang tinggi akan nutrisi protein. Selain ampas tahu, kacang hijau merupakan pangan yang tinggi akan protein.

Penelitian (Cynthia, 2013) yang berjudul kajian formulasi penambahan tepung ampas tahu terhadap sifat organoleptik dan kimia cookies. Penelitian tersebut menggunakan rancangan acak lengkap dengan enam taraf perlakuan yakni penambahan tepung ampas tahu $0 \mathrm{~g}, 20 \mathrm{~g}, 40 \mathrm{~g}, 60 \mathrm{~g}$, $80 \mathrm{~g}$, dan $100 \mathrm{~g}$. Penelitian ini menggunakan tepung terigu sebanyak 200 g. Perlakuan terbaik pada penelitian ini adalah perlakuan (A1) yaitu penambahan tepung ampas tahu $20 \mathrm{~g}$ dengan hasil organoleptik yaitu kenampakan 3,08 (menarik), warna 3,42 (agak kuning), aroma 3,03 (agak langu), tekstur 2,75 (halus), rasa 2,86 (agak berasa kedelai) dan keseluruhan 3,28 (suka). Sedangkan hasil analisa kimia, kadar air (3,42), kadar abu $(2,07 \%)$, protein $(9,04 \%)$, lemak $(34,32 \%)$, karbohidrat $(51,15 \%)$, serat kasar $(6,83 \%)$, energi $(531,08 \mathrm{kkal})$.

Alternatif bahan baku yang dapat digunakan dalam pengolahan biskuit selain ampas tahu yaitu kacang hijau. Kacang hijau merupakan tanaman tropis yang merupakan tanaman kacangkacangan terbanyak ketiga setelah kacang kedelai dan kacang tanah.

Berdasarkan data Badan Pusat Statistik (BPS) tahun 2015 produksi kacang hijau di Provinsi Riau yaitu sebanyak 598 ton. Kacang hijau yang mengandung nutrisi tinggi dapat diolah menjadi bubur kacang hijau, stik, minuman, selain itu kacang hijau juga dapat diolah menjadi tepung yang dapat digunakan dalam pengolahan biskuit.

Penelitian (Ratnasari, 2015) yang berjudul pengaruh tepung kacang hijau, tepung labu kuning, margarine terhadap fisikokimia dan organoleptik biskuit, penelitian tersebut menggunakan 
rancangan acak kelompok dengan 2 faktor dengan perlakuan 20\%:30\%, 25\%:25\%, 30\%:20\% dan perlakuan terbaik yaitu 30\%:20\% dengan kadar abu $2,77 \%$, lemak $21,66 \%$, pati $34,7 \%$, karoten 103,11mg.

Kacang hijau merupakan tanaman yang populer di Indonesia di karenakan mengandung nutrisi yang tinggi, melihat dari kandungan nutrisi serta warna yang khas pada kacang hijau maka dapat dikombinasikan dalam proses pembuatan biskuit

Dari penelitian sebelumnya tepung ampas tahu memberikan pengaruh terhadap tekstur, rasa dan mutu cookies. Selain itu biskuit kacang hijau bisa dijadikan sebagai alternatif baru dalam pengolahan pangan yang tinggi akan nutrisi. Namun belum diketahui perbandingan tepung ampas tahu yang tepat untuk menghasilkan mutu serta organoleptik yang baik pada biskuit kacang hijau.

Berdasarkan

tersebut, melakukan penelitian yang berjudul Pengaruh Penambahan Tepung Ampas Tahu terhadap Karakteristik Biskuit yang Dihasilkan.

Adapun tujuan utama dari penelitian ini yaitu :

1. Mengetahui pengaruh penambahan tepung ampas tahu terhadap kadar protein, kadar abu dan kadar air, warna, tekstur, rasa dan aroma biskuit yang dihasilkan.

2. Mengetahui perbandingan yang tepat antara tepung ampas tahu dengan tepung kacang hijau untuk mendapatkan mutu yang baik dalam pembuatan biskuit.

Adapun manfaat dari penelitian ini untuk :

1. Memberikan informasi mengenai proses pembuatan biskuit kacang hijau dengan penambahan tepung ampas tahu.

2. Meningkatkan kualitas mutu biskuit kacang hijau dengan menambahkan tepung ampas tahu pada proses pengolahannya.

\section{METODE PENELITIAN}

\section{Bahan}

Bahan utama yang digunakan pada penelitian ini adalah 200 gr tepung terigu merk boga sari, tepung ampas tahu, kacang hijau, gula halus (sukrosa), margarin, telur.

Bahan yang digunakan untuk analisa kimia adalah ,bahan pengering yaitu fosfor pentoksida kering atau butiran halus silica gel, pereaksi anthrone $0,1 \%$ dalam asam sulfat pekat, akuades, pereaksi anthrone $0,1 \%$, dalam asam sulfat pekat, akuades, asam sulfat pekat berat jenis 1,84, air raksa oksida, kalium sulfat, larutan natrium hidroksida-natrium tiosulfat (larutan 60 g Na $\mathrm{aH}_{\text {dan }} 5 \mathrm{~g} \mathrm{~N}_{\mathrm{a}} \mathrm{S}_{2} \mathrm{O}_{2} .5 \mathrm{H}_{2} \mathrm{O}$ dalam air dan encerkan sampai $100 \mathrm{ml}$ ), larutan asam borat jenuh, larutan asam klorida $0.02 \mathrm{~N}$.

Alat
Peralatan yang digunakan untuk
pembuatan biskuit yaitu oven, blender,
ayakan 80 mesh, timbangan, kompor,
mangkuk, pengukus, loyang, plastik,
spatula, pisau.
Peralatan yang digunakan untuk
analisa kimia adalah oven dengan
kisaran suhu $100^{\circ} \mathrm{C}-102^{\circ} \mathrm{C}$,cawan beserta
tutupnya, desikator, penjepit cawan dan
timbangan analitik, cawan pengabuan
terbuat dari platina lengkap dengan
tutupnya, tanur pengabuan, penjepit
cawan, pipet 1ml;5ml, tabung
reaksi,kelereng/corong kecil, water bath
$100^{\circ} \mathrm{C}$, spectrophotometer, kuvet,
pemanas kjeldahl lengkap yang


dihubungkan dengan pengisap uap melalui aspirator, labu kjeldahl berukuran $30 \mathrm{ml} / 50 \mathrm{ml}$, alat distilasi lengkap dengan erlenmeyer berpenampung berukuran $125 \mathrm{ml}$, buret $25 \mathrm{ml} / 50 \mathrm{ml}$.

\section{Metode Penelitian}

Adapun metode yang digunakan dalam penelitian ini adalah metode experimen langsung yakni mengadakan pengamatan langsung terhadap objek penelitian, dengan berat bahan yang digunakan adalah 200 gram tepung terigu dan 40 gram tepung kacang hijau. Rancangan yang digunakan adalah rancangan percobaan acak lengkap (RAL) dengan perlakuan sebagai berikut:

$\mathrm{A}=\mathrm{T}$. Ampas tahu $0 \%$ per $\mathrm{BB}$

$\mathrm{B}=\mathrm{T}$. Ampas tahu $10 \%$ per $\mathrm{BB}$

$\mathrm{C}=\mathrm{T}$. Ampas tahu $20 \%$ per $\mathrm{BB}$

$\mathrm{D}=\mathrm{T}$. Ampas tahu $30 \%$ per $\mathrm{BB}$

Perlakuan ini diulang sebanyak 3 kali dengan 4 kali perlakuan dan 3 kali ulangan dengan jumlah 12 satuan unit percobaan. Model rancangan yang digunakan adalah sebagai berikut:

$Y_{i j}=\mu+P i+E_{i j}$

Dimana:

$\mathrm{Y}_{\mathrm{ij}}=$ hasil pengamatan pada pengaruh tepung ampas tahu terhadap karakteristik biskuit yang mendapat perlakuan ke-i dan ulangan ke-j

$\mu=$ rata-rata populasi atau nilai tengah umum.

$\mathrm{Pi}=$ pengaruh perlakuan ke- $\mathrm{i}$

Eij = pengaruh sisa perlakuan ke-i dan ulangan ke-j.

Dari hasil analisa data dilakukan dengan analisa statistik. Apabila $\mathrm{F}$ hitung $>\mathrm{F}$ table (beda nyata ) maka dilanjutkan dengan uji BNT (Beda Nyata Terkecil) pada taraf nyata 5\% atau $1 \%$

\section{Pelaksanaan Penelitian}

Proses pengolahan pengaruh tepung ampas tahu terhadap karakteristik biskuit yang dihasilkan terdiri dari beberapa tahap pemerasan, pengukusan, penggilingan, pengeringan, pengayakan, penyangraian, penimbangan, pencampuran, pencetakan, pengovenan.

\section{Proses Pembuatan Tepung Ampas Tahu (Sulistiani dalam Yusnita, 2012).} yang Telah Dimodifikasi Penulis
Adapun proses pembuatan tepung ampas tahu yaitu :

\section{Sortasi}

Sortasi bertujuan untuk memilih ampas tahu yang layak dan baik untuk dijadikan tepung, dalam tahap sortasi sebaiknya memilih ampas tahu yang baru dan tidak lebih dari 24 jam.

2. Penirisan dan pengepresan.

Pengepresan bertujuan untuk mengurangi kadar air ampas tahu. Kadar air yang rendah dapat memperlambat proses pembusukan pada ampas kedelai dan mempercepat proses pengeringan. Pengepresan dapat dilakukan dengan menggunakan pengepresan hidrolik atau peras manual menggunakan kain saring.

3. Pengukusan

Pengukusan dapat berfungsi sebagai sterilisasi. Ampas tahu yang diolah menjadi tepung tidak selalu baru, ada kalanya berasal dari hasil pengolahan beberapa jam yang lalu maka untuk membunuh jasak renik yang mungkin terdapat dalam ampas tahu. pada literatur sebelumnya sterilisasi dilakukan pada suhu $121^{\circ} \mathrm{C}$ selama 15 menit, namun pada saat penelitian suhu hanya naik sampai batas maksimal $100^{\circ} \mathrm{C}$. Sterilisasi dapat membunuh semua jasad renik yang 
ada dan dapat meningkatkan daya simpan ampas tahu.

4. Pengeringan

Pengeringan menggunakan oven sebaiknya dilengkapi dengan blower agar uap air yang dihasilkan dapat segera dihembuskan keluar dari dalam oven, pengeringan dengan oven menggunakan suhu $60^{\circ} \mathrm{C}$ selama 6 jam, pengovenan dilakukan sampai kadar air apabila ditimbang beratnya konstan.

5. Penggilingan.

Penggilingan menggunakan disc mail menghasilkan ampas kering dalam bentuk butiran dengan tingkat kehalusan tertentu.

6. Pengayakan.

Tepung ampas tahu diayak dengan menggunakan ayakan 80-100 mesh, pengayakan bertujuan untuk memisahkan butiran ampas kering yang masih kasar.

\section{Proses Pembuatan Tepung Kacang Hijau ( Ratnasari, 2015) yang Telah di Modifikasi oleh Penulis.}

Adapun proses pembuatan tepung kacang hijau yaitu:

1. Pencucian.

Pencucian dilakukan untuk membersihkan kacang hijau dari sampah kecil yang terdapat dikacang tersebut.

2. Penirisan

Penirisan bertujuan untuk memisahkan kacang kedelai dengan air pencucian.

3. Penyangraian

Penyangraian dilakukan selama 3 jam pada suhu $60^{\circ} \mathrm{C}$.

4. Penggilingan.
Penggilingan dilakukan dengan menggunakan mesin penggiling tepung dengan tujuan untuk mempermudah dalam proses pengayakan.

5. Pengayakan

Pengayakan menggunakan ayakan berukuran 80-100 mesh, bertujuan untuk mendapatkan tekstur tepung yang halus.

\section{Proses Pembuatan Biskuit. (Ratnasari. 2015) yang Telah dimodifikasi Penulis.}

Adapun proses pembuatan biskuit yaitu:

1. Pencampuran

Tepung ampas tahu, tepung kacang hijau dan tepung terigu dicampur sesuai dengan perlakuan, kemudian masing-masing perlakuan ditambahkan 200 gram gula, 50 gram margarin, 2 butir telur kemudian semua bahan di campur dengan menggunakan mixer.

2. Pencetakan

Adonan yang telah jadi di cetak dengan ukuran seragam yaitu bulat dengan ukuran $4 \mathrm{~cm}$.

3. Pemanggangan

Pemanggangan dengan menggunakan oven dengan suhu $100^{\circ} \mathrm{C}$ selama 60 menit.

\section{HASIL DAN PEMBAHASAN}

\section{Kadar Air}

Hasil sidik ragam dari perlakuan penambahan tepung ampas tahu dalam pembuatan biskuit berbeda tidak nyata terhadap kadar air biskuit (lampiran 5), hal ini dikarenakan $\mathrm{F}$ hitung $<\mathrm{F}$ tabel, sehingga $\mathrm{H} 0$ diterima dan $\mathrm{H} 1$ ditolak. Rata-rata kadar air biskuit setelah uji lanjut disajikan pada Tabel 1. 
Tabel 1. Rata-Rata Hasil Analisa Kadar Air Biskuit dengan Penambahan Tepung Ampas Tahu.

\begin{tabular}{|c|c|}
\hline Perlakuan & Rata-rata $(\boldsymbol{\%})$ \\
\hline A ( Tepung ampas tahu 0\% per BB ) & 6,81 \\
\hline B ( Tepung ampas tahu 10\% per BB ) & 7,14 \\
\hline C ( Tepung ampas tahu 20\% per BB ) & 7,56 \\
\hline D ( Tepung ampas tahu 30\% per BB ) & 7,62 \\
\hline
\end{tabular}

Ket: $\mathrm{F}$ hitung $<\mathrm{F}$ tabel shingga tidak dilakukan uji lanjut

Hasil analisa kadar air menunjukan bahwa jumlah kadar air tertinggi terdapat pada perlakuan D (Tepung ampas tahu $30 \%$ per BB) yaitu sebesar $7,62 \%$ dan kadar air terendah pada perlakuan A (Tepung ampas tahu 0\%) sebesar 6,81 $\%$.

Tingginya kadar air pada perlakuan D dikarenakan ampas tahu memiliki kadar air yang pada saat dilakukan pengovenan dengan suhu 600 C dengan waktu selama 3 jam yaitu sebesar $80 \%$, selain itu kadar air yang terdapat dalam tepung ampas tahu juga menjadi faktor yang menyebabkan tingginya kadar air pada perlakuan D, namun pada saat melakukan penelitian kadar air tepung ampas tahu tidak dilakukan pengukuran sehingga tidak diketahui standar kadar air pada tepung ampas tahu yang telah dihasilkan.

Pada penelitian ini jumlah tepung terigu yang di tambahkan pada semua perlakuan sama yaitu sebanyak 200 gram namun jumlah gluten yang banyak berasal dari tepung terigu menjadi salahsatu penyebab kadar air biskuit yang dihasilkan tidak memenuhi standar mutu biskuit menurut SNI 1992 karna gluten yang tinggi dan ditambahkan dengan tepung ampas tahu dalam jumlah besar pada perlakuan D mengakibatkan tingginya kadar air pada perlakuan ini. hal ini dikarenakan gluten mampu menyerap air pada adonan dan pernyataan ini sesuai dengan pernyataan (Mutz dalam Yuliana, 2015) bahwa semakin tinggi gluten maka kemampuan adonan untuk menyerap air menjadi tinggi sehingga kadar air meningkat.

Rendahnya kadar air pada perlakuan A dikarenakan dalam perlakuan ini tidak adanya penambahan tepung ampas tahu, perlakuan A hanya menggunakan tepung kacang hijau dan tepung terigu. Kacang hijau memiliki kadar air yaitu 4,155\%, apabila di tambah dengan tepung ampas tahu sebesar $30 \%$ maka produk yang dihasilkan akan tinggi kadar air.

Hasil penelitian penunjukan bahwa kadar air yang dihasilkan belum sesuai dengan rekomendasi Standar Nasional Indonesia 1992 bahwa kadar air pada biskuit maksimal 5\%. Sedangkan kadar air yang terdapat pada biskuit lebih dari $5 \%$.

\section{Kadar Abu}

Hasil sidik ragam dari perlakuan penambahan tepung ampas tahu dalam pembuatan biskuit berbeda nyata (lampiran 6). Pengaruh penambahan tepung ampas tahu terhadap kadar abu biskuit yang dihasilkan setelah uji lanjut dapat dilihat pada Tabel 2. 
Tabel 2. Hasil Uji Lanjut Penambahan Tepung Ampas Tahu terhadap Kadar Abu Biskuit yang Dihasilkan.

\begin{tabular}{|c|c|}
\hline Perlakuan & Rata-rata (\%) \\
\hline A ( Tepung ampas tahu 0\% per BB ) & 0,83 a \\
\hline B ( Tepung ampas tahu 10\% per BB ) & $0,94 \quad$ b \\
\hline C ( Tepung ampas tahu 20\% per BB ) & $0,97 \quad$ b \\
\hline D ( Tepung ampas tahu 30\% per BB ) & $1,02 \quad$ b \\
\hline
\end{tabular}

Ket: $\mathrm{F}$ hitung > F tabel sehingga dilakukan uji lanjut BNT taraf 5\%

Hasil analisa kadar abu menunjukan bahwa perlakuan A berbeda nyata dengan perlakuan $\mathrm{B}, \mathrm{C}$ dan $\mathrm{D}$ hal ini dikarenakan pada perlakuan A merupakan kontrol (0\% tepung ampas tahu) sehingga kadar abu yang dihasilkan berasal dari mineral yang terkandung dalam tepung kacang hijau, sedangkan pada perlakuan B, C dan D berbeda tidak nyata dikarenan abu dihasilkan dari mineral yang terkandung dalam tepung kacang hijau dan tepung ampas tahu, selain itu jumlah perbandingan tepung ampas tahu pada perlakuan B, C dan D hanya berbeda $10 \%$ pada setiap perlakuan sehingga kadar abu yang dihasilkan tidak berbeda nyata.

Perlakuan B berbeda nyata dengan A dan berbeda tidak nyata dengan $\mathrm{C}$ dan $\mathrm{D}$, perlakuan $\mathrm{C}$ berbeda nyata dengan $\mathrm{A}$ dan berbeda tidak nyata dengan $\mathrm{B}$ dan $\mathrm{D}$, perlakuan $\mathrm{D}$ berbeda nyata dengan $\mathrm{A}$ dan berbeda tidak nyata dengan $\mathrm{B}$ dan $\mathrm{C}$.

Hasil analisa menunjukan bahwa jumlah kadar abu tertinggi terdapat pada perlakuan D (tepung ampas tahu 30\% per BB) yaitu $1,02 \%$ dan kadar abu terendah terdapat pada perlakuan A ( tepung ampas tahu $0 \%$ ) yaitu $0,83 \%$. Tingginya kadar abu pada perlakuan $\mathrm{D}$ bila dibandingkan perlakuan $\mathrm{B}$ dan $\mathrm{C}$ disebabkan oleh kandungan mineral yang tingginya mineral pada tepung ampas tahu sebesar 4,3 gram.

Pernyataan tersebut sesuai dengan pendapat (Andarwulan dalam Cynthia,
2013) bahwa kadar abu dari suatu bahan menunjukan kandungan mineral yang terdapat dalam bahan, kemurnian serta kebersihan suatu bahan yang dihasilkan. Bahan pangan mengandung kadar abu dalam jumlah yang berbeda, abu tersebut disusun oleh berbagai jenis mineral dengan komposisi yang beragam tergantung pada jenis dan sumber bahan pangan.

Tingginya kadar abu pada biskuit pada perlakuan D juga dapat disebabkan adanya penambahan tepung ampas tahu yang mengandung residu anorganik dalam jumlah besar, karena ukuran partikel tepung ampas tahu yang masih kasar sementara tepung terigu sangat halus, kasarnya tekstur tepung ampas tahu mengakibatkan adanya serat-serat yang berada dalam biskuit .

Selain adanya kandungan mineral pada tepung ampas tahu, kandungan protein yang tinggi menjadi faktor meningkatnya abu pada biskuit, hal ini sesuai dengan pernyataan (Amelia, 2005) bahwa kandungan abu tidaklah sepenuhya mewakili bahan anorganik pada makanan, abu dapat berasal dari bahan organik seperti sulfur dan fosfor dari protein.

Hasil penelitian menunjukan bahwa kadar abu yang dihasilkan masih sesuai dengan rekomendasi Standar Nasional Indonesia 1992 bahwa kadar abu pada biskuit yaitu maksimal 1,5\%, maka kadar abu biskuit dengan penambahan tepung ampas tahu dan 
kacang hijau masih memenuhi syarat mutu biskuit.

\section{Kadar Protein}

Hasil sidik ragam dari perlakuan penambahan tepung ampas tahu dalam pembuatan biskuit berbeda tidak nyata terhadap kadar protein (lampiran 7), hal ini dikarenakan $\mathrm{F}$ hitung $<\mathrm{F}$ tabel, sehingga H0 diterima dan $\mathrm{H} 1$ ditolak. Rata-rata kadar air biskuit setelah uji lanjut disajikan pada Tabel 3.

Tabel 3. Rata-Rata Hasil Analisa Kadar protein Biskuit dengan Penambahan Tepung Ampas Tahu.

\begin{tabular}{|c|c|}
\hline Perlakuan & Rata-rata $(\%)$ \\
\hline A ( Tepung ampas tahu 0\% per BB ) & 9,76 \\
\hline B ( Tepung ampas tahu 10\% per BB ) & 10,00 \\
\hline C ( Tepung ampas tahu 20\% per BB ) & 11,23 \\
\hline D ( Tepung ampas tahu 30\% per BB ) & 11,59 \\
\hline
\end{tabular}

Ket: $\mathrm{F}$ hitung < $\mathrm{F}$ tabel shingga tidak dilakukan uji lanjut

Hasil analisa kadar protein menunjukan bahwa jumlah kadar protein tertinggi terdapat pada perlakuan D (tepung ampas tahu 30\%) yaitu sebesar $11,59 \%$ dan kadar protein terendah pada perlakuan A (0\% tepung ampas tahu) yaitu sebesar 9,76\%. Dari jumlah ratarata pada tabel 6. Dapat dilihat bahwa semakin besar jumlah tepung ampas tahu maka akan semakin tinggi kadar protein pada biskuit tersebut.

Pada perlakuan D (30\% tepung ampas tahu) kandungan protein lebih tinggi, hal ini dikarenakan semua tepung yang digunakan memiliki kandungan protein namun pada perlakuan ini penambahan tepung ampas tahu dalam jumlah besar yaitu $30 \%$ akan meningkatkan jumlah protein, Menurut (Syafitri, 2009) kandungan protein pada ampas tahu yaitu sebesar 26,6 gram.

Tepung ampas tahu memiliki kandungan protein yang tinggi dikarenakan ampas tahu merupakan sisa perasan kedelai, hal ini sesuai dengan pendapat (Rusdi, 2011) yang menyatakan bahwa ampas tahu merupakan sisa perasan kedelai sehingga limbah ini memiliki kandungan protein yang masih tinggi.

Pada perlakuan A $(0 \%$ tepung ampas tahu) kadar protein rendah dibandingkan perlakuan B, C, dan D dikarenkan pada perlakuan ini tidak menggunkan tepung ampas tahu sehingga protein yang dihasilkan hanya protein yang berasal dari kacang hijau dan tepung terigu, menurut (Mayang, 2007) kandungan protein pada kacang hijau dapat mencapai $20-25 \%$. Namun setelah menjadi produk biskuit protein menurun dikarenakan pada saat proses pengolahan dengan cara di sangrai maka protein kacang hijau akan menurun. Hal ini sesuai dengan pendapat (Harli dalam Yuliana, 2013) bahwa cara pemasakan mempengaruhi kehilangan protein selama proses pembuatannya.

Hasil penelitian menunjukan bahwa kadar protein yang dihasilkan sesuai dengan rekomendasi Standar Nasional Indonesia 1992 bahwa kadar protein pada biskuit yaitu minimal $9 \%$, maka kadar protein biskuit dengan penambahan tepung ampas tahu dan kacang hijau memenuhi syarat mutu biskuit. 


\section{Penilaian Organoleptik}

Hasil penilaian organoleptik menunjukan bahwa warna, tekstur, rasa, dan aroma tidak berbeda nyata pada setiap perlakuan dan dapat dilihat pada radar yang tercantum pada Gambar 01 .

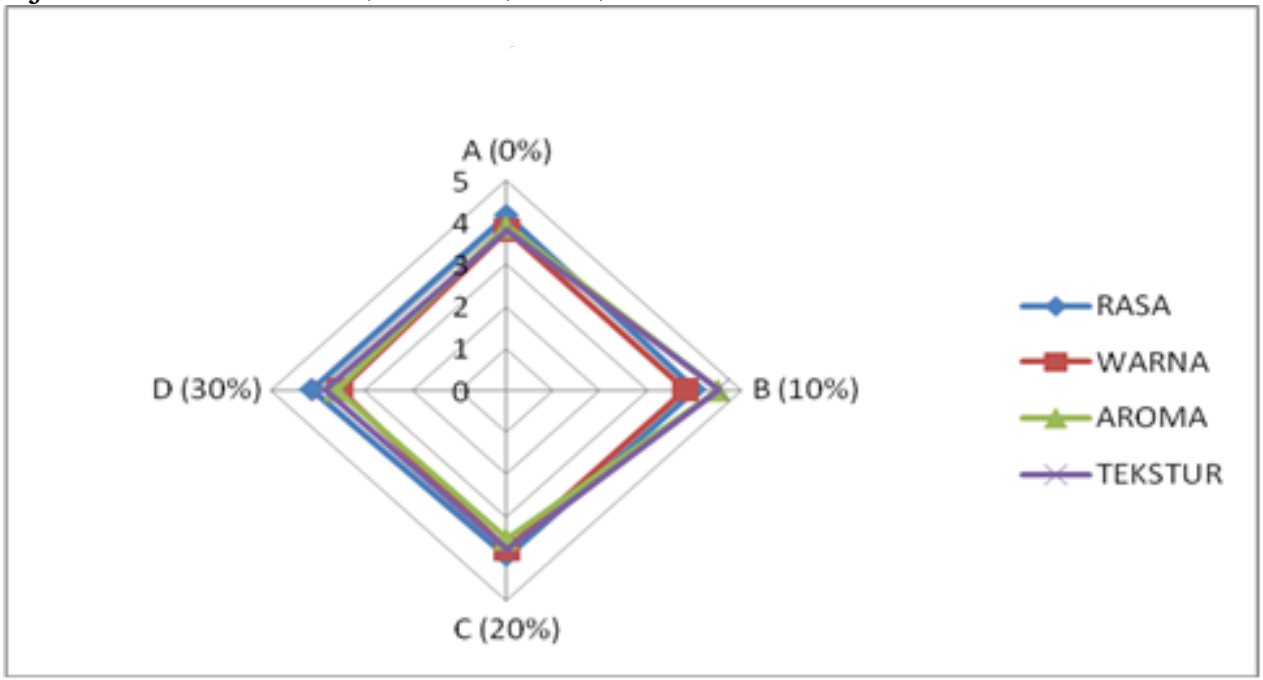

Gambar 01. Radar Organoleptik

Dari radar di atas dapat dilihat bahwa rasa tertinggi terdapat pada perlakuan $\mathrm{A}$ dan $\mathrm{D}$ dan terendah pada perlakuan $\mathrm{C}$, warna biskuit tertinggi pada perlakuan $\mathrm{A}, \mathrm{B}, \mathrm{C}$ dan terendah pada perlakuan $\mathrm{D}$, aroma biskuit tertinggi pada perlakuan A dan terendah pada perlakuan $\mathrm{C}$, tekstur biskuit tertinggi pada perlakuan B dan terendah pada perlakuan A.

\section{KESIMPULAN DAN SARAN}

\section{Kesimpulan}

Kesimpulan yang diperoleh setelah melakukan penelitian ini yaitu sebagai berikut :

1. Berdasarkan hasil penelitian yang telah dilakukan diketahui bahwa penambahan tepung ampas tahu pada pembuatan biskuit berpengaruh nyata terhadap kadar abu dan berbeda tidak nyata terhadap kadar air, kadar protein, warna, tekstrur, aroma dan rasa biskuit yang dihasilkan.
2. Hasil biskuit terbaik yaitu pada perlakuan B dengan penambahan tepung ampas tahu sebanyak $10 \%$, tepung kacang hijau $20 \%$ dan tepung terigu 200 gram dengan kadar air sebesar 7,14\%, kadar abu sebesar $0,94 \%$, kadar protein sebesar 10,00\%, dan skor organoleptik warna sebesar 3,80, tekstur 4,05, rasa 4,00 dan aroma 3,60 .

\section{Saran}

Penelitian ini menghasilkan biskuit dengan tekstur yang keras dikarenakan penambahan margarin dalam jumlah kecil, dan pada penelitian ini analisa kimia yang dilakukan hanya terhadap kadar air, kadar abu dan protein. Dari hasil penelitian tersebut maka penulis menyarankan untuk melakukan penelitian lebih lanjut yaitu :

1. Penelitian terhadap daya simpan biskuit

2. Penambahan margarin yang tepat untuk menghasilkan biskuit dengan tekstur renyah. 
3. Selain dikombinasikan dengan tepung kacang hijau pembuatan biskuit dengan tepung ampas tahu juga dapat di kombinasikan dengan tepung lainnya.

4. Melakukan analisa kadar air terhadap bahan baku terlebih dahulu, sebelum diolah menjadi biskuit. Bahan baku dalam hal ini adalah tepung ampas tahu dan tepung kacang hijau.

\section{DAFTAR PUSTAKA}

Amelia M. R, Nina D, Trisno A. 2005. Penetapan Kadar Abu. Fakultas Ekologi Manusia. Bogor.

Andriani L. 2014. Pengaruh Tepung Gaplek Sebagai Substitusi Tepung Terigu dalam Pembuatan Cookies. Fakultas Pertanian. Universitas Islam Indragiri.

Asmoro L. C, Kumalaningsih S, Mulyadi A. F. 2012. Karakteristik Organoleptik Biskuit dengan Penambahan Tepung Ikan Teri Nasi ( Stolephorus Spp. ). Fakultas Teknologi Pertanian. Universitas Bandung.

Apriyantono A, Fardiaz D, Puspitasari N, Sedarnawati, Budiyanto S. 1988. Analisis Pangan. Bogor: Institut Pertanian Bogor.

Badan Pusat Statistik. 2015. Data Statistik Tanaman Pangan. Provinsi Riau.

Barus W. A, Khair H, Siregar M. A . 2014. Respon Pertumbuhan dan Produksi Kacang Hijau ( Phaseolus Radiatus L ) Akibat Penggunaan Pupuk Organik Cair Dan Pupuk TSP. Fakultas Pertanian. UMSU Medan.

Buckle K. A, Edwards R. A, Fleet G. H, Wootton M. 2007. Ilmu Pangan. Jakarta :Universitas Indonesia.
Elfidia. 2014. Pengaruh Pengolahan Tahu terhadap Kesehatan Masyarakat.

Http://Enggangertisaya.Blogspot.C o.Id (Diakses Tanggal 15 Januari 2016).

Gustina. 2012. Pemanfaatan Ampas Tahu Sebagai Pakan Unggas. Http://Disnak. Jatimprov. Go. Id (Diakses 15 Januari 2016).

Ilmah M. 2014. Penentuan Kadar Air dan Kadar Abu dalam Biskuit. Fakultas Ilmu Tabiyah dan Keguruan. Universitas Islam Negri Syarif Hidayatul Jakarta.

Koswara. 2009. Teknologi Pengolahan Telur. Ebookpangan.Com.

Lopulalan C. G.CH, Mailoa M, Sangadji D. 2013. Kajian Formulasi Penambahan Tepung Ampas Tahu terhadap Sifat Organoleptik dan Kimia Cookies. Fakultas Pertanian. Universitas Patimura.

Mayang A. 2007. Formulasi dan Optimasi Produk Biskuit Berbahan Baku Sagu Ubi Jalar dan Kacang Hijau. Fakultas Teknologi Pertanian. Institut Pertanian Bogor.

Mervina. 2009. Formulasi Biskuit dengan Subsitusi Tepung Ikan Lele Dumbo ( Clarias Gariepinus) dan Isolat Protein Protein Kedelai Sebagai Makanan Potensial Untuk Anak Balita Gizi Kurang. Fakultas Ekologi Manusia. Institut Pertanian Bogor.

Nurhidajah, Waysima, Wulandari $\mathrm{N}$. 2010. Kajian Teknologi Pembuatan Tepung Kacang Hijau Instan dan Sifat Fisik. Jurnal Pangan dan Gizi.

Rahman T, Triyono A. 2011. Pemanfaatan Kacang Hijau Menjadi Susu Kental Manis Kacang Hijau. Prosiding Seminar Nasional. 
Ratnasari D. Yunianta. 2015. Pengaruh Tepung Kacang Hijau, Tepung Labu Kuaning, Margarin terhadap Fisikokima dan Organoleptik Biskuit. Jurnal Pangan dan Agroindustri.

Ridhoresmi D. 2012. Pengaruh Subsitusi

Tepung Ampas Tahu terhadap

Kadar Protein dan Daya Terima

Brownis. Fakultas Ilmu Kesehatan.

Universitas Muhammadiayah

Surakarta.

Rusdi B, Maulana I. T, Kodir R. A.

2011. Analisis Kualitas Tepung

Tahu. Fakultas Farmasi.

Universitas Islam Bandung.

Sarjono P. R, Mulyani N. S, Amin A. L.

N, Waryanti. 2006. Profil

Kandungan Protein dan Tekstur

Tahu Akibat Fitat Pada Proses

Pembuatan Tahu. Fakultas Kimia.

Universitas Diponegoro.

Saputro T. 2015. Ampas Tahu Untuk

Pakan Ternak. Http://Www.

$\underline{\text { Ilmuternak.Com (Diakses Tanggal }}$

16 Januari 2016).

Syafitri D. 2009. Pengaruh Subsitusi

Tepung Ampas Tahu Pada Kue
Ulat Sutra terhadap Kualitas Organoleptik dan Kandungan Gizi.

Fakultas Teknik. Universitas Negri Semarang.

Storytime. 2015. Asal Usul dan Lebih Dekat dengan Tepung Terigu. Https://Syadanida.Blogspot.Co.Id

(Diakses 16 Januari 2016).

Wati R. 2013. Pengaruh Tepung Ampas Tahu sebagai Bahan Komposit terhadap Kualitas Kue Kering Lidah Kucing. Fakultas Teknik. Universitas Negri Semarang.

Winarno F. G. 1992. Kimia Pangan dan Gizi. Jakarta:PT. Gramedia Pustaka Utama.

Yuliana. 2013. Pengaruh Subsitusi Tepung Terigu dengan Tepung Pisang Kapok terhadap Karakteristik Mie Kering yang dihasilkan. Fakultas Pertanian. Universitas Islam Indragiri.

Yustina I, Abadi F. R. 2012. Potensi Tepung Ampas Industri Pengolahan Kedelai sebagai Bahan Pangan. Fakultas Pertanian. Universitas Trunojoyo Madura. 